\title{
WOJCIECH DAJCZAK
}

Uniwersytet im. Adama Mickiewicza w Poznaniu

\section{PROBLEM „PONADCZASOWOŚCI” ZASAD PRAWA RZYMSKIEGO. UWAGI W DYSKUSJI $\mathrm{O}$ „NOWEJ EUROPEJSKIEJ KULTURZE PRAWNEJ”}

\section{WPROWADZENIE}

Postępy procesu globalizacji, integracji regionalnej w Europie i rozwój orzecznictwa ponadnarodowych trybunałów sprawiły, że od początku XXI stulecia ożywiła się dyskusja nad poszukiwaniem uniwersalnych zasad prawa. W refleksji nad tym jak i gdzie ich poszukiwać uwaga kieruje się w szczególności ku prawu rzymskiemu. Są jednak istotne różnice w podejściu do tego doświadczenia prawniczego. Przykładowo, Antonio Garrigues Walker przedstawił pogląd, że prawo rzymskie w którym historycznie zakorzenione są współczesne porządki prawne, ma istotne miejsce w formułowaniu reguł prawa światowego (derecho global) ${ }^{1}$. Całkowicie odmiennie stanowisko zajmuje w szczególności Martijn W. Hesselink. Próby poszukiwania uniwersalnych reguł w rzymskich źródłach kwalifikuje on jako neopandektystykę, którą postrzega jako jeden $z$ nowych formalistycznych trendów w prawoznawstwie. Odrzuca takie podejście, akcentując potrzebę nowej europejskiej kultury prawnej, któ-

'A. Garrigues Walker, Prologo, [w:] Principios de Derecho Global. Aforismos juridicos comentados, red. R. Domingo, J. ORTEGA, B. RodrigueZ-Antolin, Navarra 2003, s. 17. 
rą promuje pod hasłem realizmu w prawie prywatnym, wyrażającego się w tym, iż będzie ono mniej dogmatyczne, a bardziej będzie instrumentem realizacji celów politycznych, ekonomicznych, socjalnych czy kulturalnych².

Naszkicowany spór rodzi pytanie, czy realistyczne podejście do prawa pozwala pominąć fakt trwałości zasad wyrastających z prawa rzymskiego? Jako zasadę rozumiem tu ratio decidendi, na której opiera się rozstrzygnięcie konkretnego konfliktu w prawie, to jest analogicznie do reason of deciding $w$ angielskim common law ${ }^{3}$.

W ramach doświadczenia antycznego prawa rzymskiego, najważniejsze znaczenie dla odnajdywania oryginalnych rationes decidendi miała jurysprudencja późnej republiki oraz trzech pierwszych wieków naszej ery. $Z$ tego powodu ograniczę się do tych prawników i istotnych dla niniejszych rozważań cech ich metody znajdowania rozstrzygnięć.

\section{REALIZM RZYMSKICH JURYSTÓW}

Julius Paulus wyjaśniając u schyłku klasycznej jurysprudencji sens pojęcia regula stwierdził, iż non ex regula ius sumatur, sed ex iure quod est regula fiat ${ }^{4}$ i powołując się na żyjącego ponad 100 lat wcześniej Sabinusa, dodał, że w konkretnym przypadku, z uwagi na jego okoliczności, regula może utracić znaczenies. Takie stwierdzenie wyróżniającego się zdolnością syntezy i budowania definicji Paulusa ${ }^{6}$ sygnalizuje realizm $\mathrm{w}$ podejściu do prawa polegający na łączeniu prawa $z$ rozstrzyganym przypadkiem i odrzucający budowanie prawa w drodze rozumowej spekulacji. Innymi słowy, roz-

${ }^{2}$ M.W. Hesselink, The New European Private Law. Essays on the Future of Private Law in Europe, The Hague 2002, s. 59 i 65.

${ }^{3}$ Por. R. Cross, J.W. Harris, Precedent in English Law, Oxford 1991, s. 39 i n.

${ }^{4}$ D. $50,17,1$ : prawo nie wynika $\mathrm{z}$ reguły, ale reguła powstaje na podstawie istniejącego prawa.

${ }^{5}$ D. $50,17,1$ in fine.

${ }^{6}$ J.L. Murga, Julio Paulo, [w:] Juristas universales, I, red. D Domingo, Madrid 2004, s. 206. 
strzyganie wątpliwości prawnych było postrzegane nie jako tworzenie, ale jako odkrywanie rationes decidendi trafnego rozstrzygnięcia przypadku. W zachowanych fragmentach z dzieł jurystów znajdujemy teksty, które wyraźnie ilustrują charakter i zakres wskazanego realizmu w znajdowaniu i stosowaniu prawa. Można je usystematyzować według podejścia do: obiektów otaczającego świata materialnego; świata zastanych instytucji prawnych oraz sposobu argumentowania na podstawie sądu wartościującego.

\subsection{Podejście jurystów do świata materialnego}

Istotę podejścia jurystów do obiektów materialnych można sprowadzić do zasady, iż w prawie muszą być uwzględnione i nie mogą być zmienione immanentne im właściwości․ Jako ilustrujące ją przykłady można wskazać to, że juryści w oparciu o doświadczalnie uchwytne właściwości rozróżniali rzeczy podzielne i takie, których bez uszkodzenia (sine interitu) podzielić się nie da ${ }^{8}$. Od rzeczy ruchomych (mobiles aut se moventes) odróżniali jako nieruchomość tylko grunt traktowany jako jedność z tym co jest z nim trwale związane (quae soli sunt, quae solo continentur) ${ }^{9}$. Uznawali zasadność różnego traktowania w prawie gęsi i kur domowych oraz żyjących $\mathrm{w}$ stanie dzikim ${ }^{10}$. Jako wyraz realizmu jurystów można przyjąć fakt, iż dążąc do właściwego uchwycenia obiektów materialnych korzystali z ustaleń filozofii, która była wówczas nauką tłumaczącą świat. Takie podejście wyraźnie oddaje, wykorzystany przez Pomponiusa w rozważaniach nad zdolnością do zasiedzenia, podział corpora na trzy rodzaje: jednolite, np. kamień, drewno;

${ }^{7}$ Por. W. Waldstein, Saggi sul diritto non scritto, Padova 2002, s. 24 i n.

${ }^{8}$ D. $6,1,35,3$.

${ }^{9}$ D. $21,1,1$ pr.; D. 6,1,1,1. Co do traktowania przez jursytów rzymskich gruntu i posadowionych na nim budynków jako elementów jednej całości ostatnio: R. ŚwIRGOŃ-SKOK, Akcesja do nieruchomości w prawie rzymskim, [w:] Wspótczesna romanistyka prawnicza $w$ Polsce, Lublin 2004, s. 298.

${ }^{10}$ D. $41,1,5,6$. 
złożone (inter se contingentibus), jak np. dom, statek oraz zbór rzeczy (quod ex distantibus constat), jak stado ${ }^{11}$. Podobnie ocenić można wywód Juliana, który rozważając możliwe następstwa tego, że spadkodawca pozostawił ciężarną żonę uznał, że liczba spadkobierców może wzrosnąć o pięcioro „bowiem Arystoteles napisał, że może urodzić się pięć osób, ponieważ łona kobiet mogą mieć tyle możliwości”. Dalsze słowa Juliana, iż „w Rzymie jest kobieta Aleksandryjka z Egiptu, która naraz urodziła pięcioro dzieci i pozostała w dobrym stanie, i to potwierdzono mi także w Egipcie"12 ilustrują, że korzystanie przez jurystów z dorobku filozofów nie byto bezkrytyczne. W przypadkach, gdy tłumaczenie materialnego świata rodziło kontrowersje wśród filozofów, znajduje to swoją paralelę w sporach jurystów. Kwestię tę dobrze oddaje pytanie o tożsamość rzeczy powstałej w wyniku przetworzenia, którego odpowiednikiem $\mathrm{w}$ prawie była kontrowersja pomiędzy sabinianami i prokulianami, co do tego, kto jest właścicielem rzeczy powstałej w wyniku przetworzenia. Problem lokuje się w ramach czytelnego sporu pomiędzy perypatetykami dla których o tożsamości decyduje forma i stoikami, według których o tożsamości rzeczy przesądzała materia ${ }^{13}$. Jest sporne jaki był mechanizm oddziaływania tej kontrowersji filozofów na rzymskich jurystów ${ }^{14}$. Uznając znaczną samodzielność prawników w podejściu do tego problemu, warto wskazać ustalenia nauki pokazujące dążenie do uwzględnienia obiektywnych cech materii. Tak odczytać można pogląd, że sabinianie wykluczali zmianę własności w wyniku przetworzenia, ponieważ wierzyli, że „species nie może być tworzona poprzez prawo,

${ }^{11}$ D. $41,3,30$ pr.

${ }^{12}$ D. $46,3,36$.

${ }^{13}$ M. SCHERMAIER. 'Materia'. Beiträge zur Frage der Naturphilosophie im klassischen römischen Recht, Wien-Köln-Weimar 1992, s. 213 i n.

${ }^{14}$ Por. P. SokoLowsKI, Die Philosophie im Privatrecht. Sachbegriff und Körper in der klassischen Jurisprudenz und der modernen Gesetzgebung, Halle 1907 [unveränderter Neudruck, Aalen 1959], I, s. 74 i n.; odmiennie M. SCHERMAIER, op. cit., s. 223. 
w oderwaniu od materii”'เs. Podobnie rozumieć można tezę, że osiągnięty w ramach rzymskiej jurysprudencji kompromis polegający na tym, że przetworzenie prowadziło do nabycia własności, gdy nie można było przywrócić rzeczy do stanu pierwotnego, łączyć należy z dążeniem do zgodności pomiędzy nazwaniem i możliwością zobaczenia tego co się windykuje ${ }^{16}$.

W trudnościach poznania świata materialnego można upatrywać jednej z przyczyn kontrowersji pomiędzy rzymskimi jurystami. Nie podważa to jednak, zilustrowanej powyższymi przykładami realistycznej postawy, sprowadzającej się do tezy, iż w poszukiwaniu prawa muszą być uwzględnione właściwości przedmiotów materialnych ${ }^{17}$.

\subsection{Podejście jurystów do zastanych instytucji prawnych}

W tekstach jurystów znajdujemy także wypowiedzi, w których deklarowali oni uniwersalne cechy instytucji prawnych. Przykładowo: Ulpian powtarza zdanie Pediusa, iż kontrakt nie może dojść do skutku bez porozumienia stron ${ }^{18}$. Labeo jednoznacznie odróżnił pomiędzy przyznaniem skargi z tytułu użyczenia bądź najmu w zależności od tego, czy powodowi przysługuje czynsz za korzystanie z rzeczy której zwrotu żąda ${ }^{19}$. Z przekazu Pomponiusza dowiadujemy się, że jest naturalna sprzeczność pomiędzy dziedziczeniem testamentowym i beztestamentowym, wyłączająca zbieg tych sposobów powołania do spadku po jednej osobie ${ }^{20}$. Takie wypowiedzi zakładają istnienie precyzyjnie określonych figur prawnych: kontraktu, użyczenia, czy testamentu do których się odwołują. Zestawienie takiego założenia $\mathrm{z}$ faktami, iż w pra-

\footnotetext{
${ }^{15}$ M. TAlamanCA, Istituzioni di diritto romano, Milano 1989, II. 1, s. 420.

${ }^{16}$ F. WIEACKER, Spezifikation. Schulprobleme und Sachprobleme, [w:] Festschrift Rabel, II, Tübingen 1954, s. 287 i n.

${ }^{17}$ W. WALDSTEIN, op. cit., s. 25.

${ }^{18}$ D. $2,14,1,3$.

${ }^{19}$ D. $13,6,5,12$.

${ }^{20}$ D. $50,17,7$.
} 
wie rzymskim zmianę wierzyciela dopuszczono tylko dzięki skardze analogicznej ${ }^{21}$ oraz, że nie przyjęto w powszechnym prawie testamentowym, znanej dzięki fideikomisom, możliwości przyznania tylko ułamkowej części majątku dziedzicom ustawowym skłania do wniosku, iż realizm rzymskich jurystów nakazujący uwzględniać to co jest pierwotne względem porządku prawnego zakładał także istnienie struktur prawnych, które są „realne”22, mogą być przyjęte, ale nie mogą być zmienione przez prawodaw$c^{23}$. Takie podejście do prawa nie usuwało jednak wątpliwości co do granic uznanych instytucji, wyciągania $z$ nich szczegółowych rozwiązań problemów nie mieszczących się w ramach uznanej figury prawnej. Tego rodzaju wątpliwości wskazać można jako drugą przyczynę kontrowersji pomiędzy rzymskimi jurystami. Nie podcina to jednak tezy o istnieniu prawnych determinationes w sporach ad casum.

\subsection{Podejście do aksjologicznych podstaw porządku prawnego}

Okko Behrends rozwinął teorię zgodnie z którą w klasycznym prawie rzymskim tkwiło przeciwieństwo pomiędzy dominującym myśleniem według instytucji prawnych oraz korygującym i uzupełniającym je poszukiwaniem rozwiązań opartych na zasadzie „naturalnej, kooperatywnej solidarności”24. Posługując się tą konstrukcją teoretyczną można tłumaczyć, że wskazane wyżej przekonanie o obiektywnej naturze zastanych instytucji prawnych było przeszkodą dla ich odrzucenia w imię „naturalnej zasady sprawiedliwości”. Ilustruje to wyraziście akceptacja dla niewoli jako instytucji prawnej, mimo, że w tekstach jurystów spotykamy zdanie, iż według ius

${ }^{21}$ Por. W. Rozwadowski, Przelew wierzytelności w prawie rzymskim, Poznań 1969, s. 159 i n.

${ }^{22}$ O. BEHRENDS, Institutionelles und prinzipielles Denken im römischen Privatrecht, «ZSS» 95 (1978), s. 227.

${ }^{23}$ W. WALdSTEIN, op. cit., s. 28.

${ }^{24}$ O. Behrends, op. cit., s. 192 i 219. 
naturale wszyscy ludzie są równi ${ }^{25}$. Z drugiej strony, przyjęty przez O. Behrenda model odwołuje się wprost do istnienia pierwotnych względem porządku prawnego, obiektywnych zasad według których powinno być porządkowane funkcjonowanie społeczności ludzkiej. Dla weryfikacji takiego obrazu pomocne jest zestawienie konkluzji O. Behrendsa co do natury bona fides w prawie klasycznym $\mathrm{z}$ wybranymi ustaleniami na ten temat, sformułowanymi na innej podstawie źródłowej i inną metodą. Wskazany romanista niemiecki określił bona fides jako pojęcie pozwalające na recepcję stoickiej filozofii prawa i społeczeństwa według której człowiek jest elementem naturalnego porządku na który składają się zasady dobrego, solidarnego współżycia ${ }^{26}$. Wolfgang Waldstein, w ogólnych rozważaniach nad, jak to określił „przedpozytywnymi” elementami rzymskiego porządku prawnego, wyróżnił jako jeden z nich bona fides, którą tłumaczył jako uczciwość i szczerość. Akcentował jej wpływ na rozwój prawa ${ }^{27}$. W szczegółowych rozważaniach nad operowaniem zwrotem bona fides w rzymskiej praktyce kontraktowej sformułowałem w szczególności wniosek, że był on pomocny jurystom przy „przekładaniu” ich filozoficzno-prawnych wyobrażeń o celach prawa na konkretne rozwiązania dotyczące kontraktów chronionych skargami bonae fidei bez podważania ustalonych figur prawnych $^{28}$.

Wskazane podobieństwo ustaleń pokazuje, moim zdaniem, iż realizm rzymskich jursytów rozciągał się także na przekonanie o istnieniu poza prawem zasad na które powinny być zorientowane wartościujące sądy prawników. Oczywiście subiektywna decyzja jurysty co do konkretyzacji i aplikacji zasady, np. co to tego, czy umownie można wyłączyć odpowiedzialność z tytułu winy umyślnej ${ }^{29}$ stwarzała warunki dla powstawania kontrowersji pomiędzy prawnikami.

${ }^{26}$ O. BEHRENDS, op. cit., s. 217 i n.

${ }^{27}$ W. WALDSTEIN, op. cit., s. 29 i n.

${ }^{28}$ W. DAJCZAK, Zwrot 'bona fides' w rozstrzygnięciach dotyczących kontraktów u prawników rzymskich okresu klasycznego, Toruń 1998 s. 150 i n.

${ }^{29}$ Por. D. 50,17,23; D. 16,3,1,7. 
3. „PONADCZASOWOŚć” ZASAD PRAWA W WYMIARZE ANTYCZNEGO PRAWA RZYMSKIEGO

Powyższe uwagi są ilustracją dostrzegalnego u rzymskich jurystów przekonania o istnieniu „ponadczasowych” zasad prawa wynikających z konieczności podporząakowania rationes decidendi pierwotnym względem prawa pozytywnego: naturze obiektów materialnych, zastanych instytucji prawnych oraz budujących wspólnotę wartości. Przekonanie to nie wyłączało kontrowersji co do konkretnych rationes. Źródła pokazują, że juryści różnili się wielokrotnie. Stąd oczywiście nie można traktować uznania przez jurystę ratio decidendi jako prawdziwą (verum) za test „ponadczasowości” zasady rozstrzygnięcia. Jednak w tym „morzu kontrowersji” wyłaniały się w dłuższej perspektywie czasu ,jak wyspy” stabilne rozwiązania. Stały kontakt rzymskiej jurysprudencji z praktyką służył weryfikacji rationes. Przykładowo, wypowiedziane przez tworzącego na przełomie II i III wieku Papiniana ogólne wskazanie, iż w skargach dobrej wiary należy uwzględniać zgodny zamiar kontrahentów $w^{30}$ jest syntetycznym wyrazem dostrzegalnej w źródłach od połowy I w. n.e. praktyki takiego stosowania klauzuli ex fide bona w konkretnych przypadkach ${ }^{31}$. Powtarzając za amerykańskim sędzią Munroe Smithem, iż praktyka rzymskich prudentes przypomina ,wielkie laboratorium prawa" ${ }^{32}$ można dodać, iż zostały w nim „odkryte” zasady, które w ramach praktyki prawnej antycznego Rzymu wykazały cechę ponadczasowości i które w części, do dziś w szeregu systemach prawnych, uznaje się za aktualne.

Kwestionując uznanie tych faktów za przejaw istnienia „ponadczasowych" zasad prawa można, co do okresu antycznego powtórzyć słowa, że prawnicy rzymscy kładli nacisk na tradycję i kontynuację bo dostrzegali w tym legitymizację autorytetu juryspruden-

${ }^{30}$ D. $17,1,54$ pr.

${ }^{31}$ Por. W. DAJCZAK, Zwrot, cit., s. 125 i n.

${ }^{32}$ M. SMITH, Jurisprudence, 1909 (cytuję za: F. SchULZ, Prinzipien des römischen Privatrechts, Berlin 1954, s. 11). 
$\mathrm{cji}^{33}$. Co do czasów nowożytnych, aż do XX. stulecia, można ograniczyć się do przyznania, że obecność rzymskich reguł jest efektem tradycji polegającej na sięganiu do prawa rzymskiego przez naukę prawa prywatnego. Spójrzmy zatem do jakich refleksji prowadzi spojrzenie z dzisiejszej perspektywy na naszkicowany wyżej model znajdowania zasad prawa przez Rzymian i ich trwałość po współczesność.

\section{OBECNOŚć ZASAD ZNANYCH Z PRAWA RZYMSKIEGO WE WSPÓŁCZESNEJ PRAKTYCE PRAWNEJ}

\section{1. Świadome odniesienia do prawa rzymskiego we współczesnym prawie prywatnym}

Nie można zaprzeczyć, że tradycja prawna, rozumiana jako obecność elementów przeszłości w teraźniejszości ${ }^{34}$ była drogą po której dotarła do współczesnych prawników wiedza o prawie rzymskim. Odnosząc się do świadomych odniesień do prawa rzymskiego we współczesnej praktyce należy w pierwszym rzędzie rozróżnić pomiędzy porządkami prawnymi, których składnikiem jest prawo rzymskie i innymi systemami prawa. Prawo rzymskie jako prawo obowiązujące ma dziś znikome znaczenie, ograniczone na naszym kontynencie do Republiki San Marino i Szkocji35. Sposób podejścia do prawa rzymskiego w tych krajach ilustruje, powtarzane w orzecznictwie San Marino, wyjaśnienie pojęcia ius commune jako źródła prawa. Zgodnie z ustaloną w ten sposób definicją ius commune stanowi prawo „oparte na podstawach prawa

${ }^{33}$ T. GIARO, Dogmatische Wahrheit und Zeitlosigkeit in der römischen Jurisprudenz, «BIDR» 90 (1987), s. 103 i n.

${ }^{34}$ Por. H. P. GlenN, Legal Traditions of the World, Oxford 2000, s. 11 i n.

${ }^{35}$ Poza kontynentem europejskim taki wolor ma prawo Republiki Południowej Afryki, Namibii i Zimbabwe, por. R. ZimmermanN, 'Usus Hodiernus Pandectarum', [w:] Europäische Rechts- und Verfassungsgeschichte, red. R. SCHulze, Berlin 1991, s. 61 i n. 
rzymskiego, kanonicznego i zwyczajowego, które powstało i rozwinęło się w cywilizowanych krajach Europy kontynentalnej, w szczególności Italii" ${ }^{36}$. Takie rozumienie prawa powszechnego daje możliwość wskazywania jako rationes decidendi także zasad niemieckiego czy francuskiego kodeksu cywilnego rozwijających romanistyczną tradycję $e^{37}$. Mimo tak szerokich, potencjalnie, możliwości odniesień jest szereg wyroków w których rozstrzygnięcia są oparte na cytatach tekstów rzymskich jurystów zachowanych poprzez justyniańskie Digesta ${ }^{38}$.

Odniesienia do prawa rzymskiego spotykamy także w porządkach prawnych których źródła nie obejmują prawa rzymskiego. $\mathrm{Z}$ punktu widzenia pytania o przyczyny trwałości zasad prawa rzymskiego nie można ich traktować jednolicie. Przykładowo, w sprawie rozstrzygniętej wyrokiem Sądu Apelacyjnego w Poznaniu z 22.06.1995 r. zasadniczy problem prawny polegał na tym, czy oddanie w dzierżawę przez dłużnika rzeczy, którą przewłaszczył na zabezpieczenie może być zakwalifikowane jako przestępstwo przywłaszczenia. W uzasadnieniu wyroku sąd w szczególności naszkicował pojęcie fiducji w prawie rzymskim. Istotny dla rozstrzygnięcia, cywilistyczny fragment argumentacji, został jednak oparty wyłącznie na przepisach kodeksu cywilnego o umowie użyczenia $^{39}$. Odniesienie do prawa rzymskiego można więc tu sprowadzić do przejawu erudycji sędziego sprawozdawcy. Od takiego podejścia odróżnić możemy powołanie rzymskiej zasady, która nie jest elementem obowiązującego prawa, ale rzeczywiście oddaje myśl, na której opiera się sędziowska argumentacja ad casum. Przykładem takiego podejścia jest uchwała Sądu Najwyższego z roku 1992. Zasadniczy problem prawny w sprawie sprowadzał

${ }^{36}$ M. Reinkenhof, Die Anwendung von 'ius commune' in der Republik San Marino. Einführung in der Grundlagen und Erbrecht, Berlin 1997, s. 76 i n. (tamże orzecznictwo).

${ }^{37}$ M. REINKENHOF, op. cit., s. 100.

${ }^{38}$ M. REINKENHOF, op. cit., s. 158 i n.

${ }^{39}$ Wyrok S.A. w Poznaniu z dnia 22.06.1995, sygn. AKr 178/95 (niepubl.). 
się do wykładni pojęcia dobrej wiary nabywcy samochodu od osoby nieuprawnionej. Sąd uznał, że za nabywcę w dobrej wierze może być uznana jedynie osoba, która „przedsięwzięła szereg czynności celem upewnienia się, w ramach ogólnego doświadczenia życiowego (...) co do stanu prawnego nabywanego samochodu". Punktem wyjścia dla takiego rozumowania było stwierdzenie, że „W polskim ustawodawstwie cywilnym obowiązuje, (...) w formie niepisanej, ogólna zasada, że nikt nie może przenieść na inną osobę więcej praw aniżeli jemu przysługuje, w myśl rzymskiej paremii nemo plus iuris in alium transferre potest, quam ipse habet oraz myśl, iż art. 169 k.c. jest wyjątkiem od tej zasady ${ }^{40}$. Odróżnione powyżej dwa przypadki ilustrują, iż nie każdy przypadek dzisiejszych odniesień do prawa rzymskiego może być uznany za dowód praktycznej uniwersalności jego zasad ${ }^{41}$. Drugi ze wskazanych przypadków nie pozwala jednak sprowadzić cytatów z rzymskich źródeł wyłącznie do formalizmu, czy tradycjonalizmu specyficznego języka prawniczego ${ }^{42}$. Można jednak podnieść wątpliwość, czy trwałość niektórych rzymskich rationes decidendi jako składnika obowiązującego prawa lub w ramach świadomych odniesień do prawa rzymskiego nie jest jedynie wynikiem konserwatyzmu kultury prawnej. Dla oceny tej kwestii cenne jest, moim zdaniem, zwrócenie uwagi na nie inspirowane historycznie powroty znanych $\mathrm{z}$ prawa rzymskiego rationes oraz dostrzeżenie, iż można wskazać sygnalizowane przez praktykę słabości rozwiązań zrywających z rzymskim doświadczeniem. Każdą z takich sytuacji zilustruję przykładem.

${ }^{40}$ «OSNCP» $1992 \mathrm{nr} 9$, poz. 144.

${ }^{41}$ Por. także: W. DAJCZAK, Łacińskie terminy i paremie w polskim orzecznictwie do prawa rzeczowego BGB z lat 1920-1939, «CPH» 55.2 (2003), s. 265 i n.

${ }^{+2} \mathrm{~W}$. WoŁODKIEWICZ, Łacińskie paremie prawne w orzecznictwie sqdów polskich, [w:] Łacińskie paremie $w$ europejskiej kulturze prawnej $i$ orzecznictwie sądów polskich, red. W. WoŁodKIEWICZA, J. KRZYNóWKA, Warszawa 2001, s. 21, wyraził pogląd, że wiele paremii łacińskich jest ,jedynie przejawem ezoterycznego języka prawniczego". 


\subsection{Niezamierzone podobieństwa do prawa rzymskiego we współczesnej praktyce prawnej}

Ciekawym przykładem, oderwanego od wiedzy o prawie rzymskim, powrotu myśli prawniczej jest kwestia istoty kary umownej i wynikających stąd przesłanek jej dochodzenia. W naszej literaturze $^{43}$ i orzecznictwie ${ }^{44}$ do roku 2000 czytelny był pogląd, iż kara umowna przewidziana $\mathrm{w}$ art. 483 k.c. stanowi odszkodowanie umowne i dlatego przysługuje na zasadzie winy. W wyroku z 27.06.2000 Sąd Najwyższy zmienił pogląd co do istoty kary umownej ${ }^{45}$. Odnosząc się do wcześniejszych poglądów na ten temat, sąd stwierdził, że ograniczano się w nich do funkcji odszkodowawczej kary umownej, a pomijano jej funkcję stymulującą. W ten sposób uznawano winę dłużnika za konieczną przesłankę kary umownej. Wprowadzając do swojej argumentacji funkcję stymulującą kary umownej Sąd Najwyższy „nie podzielił” wcześniejszych poglądów. Sędziowie uznali, że możliwość umownego rozszerzenia zakresu odpowiedzialności (art. $473 \S 1$ k.c.) pozwala stronom na zastrzeżenie kary umownej także dla przypadków niewykonania lub nienależytego wykonania zobowiązania za które według zasad ogólnych dłużnik nie odpowiada, czyli oderwanie wymagalności kary umownej od winy dłużnika. Problem zawinienia dłużnika jako przesłanki wymagalności kary umownej (świadczenia ze stipulatio poenae) był przedmiotem zainteresowania i kontrowersji już u rzymskich jurystów ${ }^{46}$. W ramach tej kazuistyki czytelnie wyłania się zasada wykluczająca żądanie kary umownej w przypadku,

${ }^{43}$ Por. M. Piekarski, [w:] Kodeks cywilny. Komentarz, Warszawa 1972, II, s. 1185; A. RĘBIELIŃSKI, [w:] Kodeks cywilny z komentarzem, Warszawa 1989, I, s. 497; W. PopioŁeK, [w:] Kodeks cywilny. Komentarz, I, Warszawa 1999, s. 1170.

${ }^{44}$ Por. np.: wyrok SN z 20.03.1968, II CR 419/67 (Lex nr 8159); wyrok SN z 29.12.1978, IV CR 440/78 (Lex nr 8159).

${ }^{45}$ Wyrok SN z 27.06.2000 r., I CKN 791/98 (nie publ.).

${ }^{46}$ Por. R. Zimmermann, The Law of Obligations. Roman Foundations of the $\mathrm{Ci}$ vilian Tradition, Oxford 1996, s. 105 i n. 
gdy niewykonanie lub nienależyte wykonania zobowiązania wynikło z przyczyn leżących po stronie wierzyciela ${ }^{47}$. W polu wytyczonym tą zasadą, łączono wymagalność kary umownej ze standardem odpowiedzialności ad casum i w konsekwencji nie uznawano jej koniecznego związku z winą dłużnika ${ }^{48}$. Dostrzegalne jest zatem funkcjonalne podobieństwo pomiędzy takimi rzymskimi rationes decidendi, a wskazaną wyżej argumentacją Sądu Najwyższego w orzeczeniu $z$ roku 2000.

Przejdźmy do przypadku zerwania z rzymskim doświadczeniem prawniczym. W ramach dyskusji nad harmonizacją prawa prywatnego w Europie jednym $\mathrm{z}$ charakterystycznych jej punktów jest, znana w prawie niemieckim, zasada odrywająca ważność czynności prawnej przenoszącej własność od istnienia i prawidłowości przyczyny przeniesienia własności (tzw. Abstraktionsprinzip) ${ }^{49}$. Ocena jej użyteczności nie jest $\mathrm{w}$ literaturze jednolita. Można jednak wskazać, oparte na analizie praktyki, krytyczne oceny tej zasady. W odniesieniu do przewłaszczania ruchomości takie ustalenia daje ostatnio M. Kaspar formułując w szczególności wniosek, że „zasada abstrakcyjności wykazuje w szeregu przypadkach wyraźnie deficyty" i w dlatego, jego zdaniem, powinno dojść do jej zastąpienia w Niemczech przez kauzalną czynność przenoszącą własnośćso. Do podobnej konkluzji doprowadziła mnie analiza obecności tej zasady w polskim orzecznictwie, na gruncie niemieckiego kodeksu cywilnego, dotyczącym sprzedaży nieruchomości. Stwierdziłem, że przy rozstrzyganiu przypadków nietypowych, wywołanych koniecznością administracyjnej zgody na przewłaszczenie, rodziła ona wątpliwości interpretacyjne. Ewolucja rozstrzygającego je orzecz-

${ }^{47}$ Por. D. 4,8,23,3; D. 22,2,8.

${ }^{48}$ Por. R. Zimmermann, The Law, cit., s. 106 (tamże odniesienia do źródel).

${ }^{49}$ Por. par. 873 k.c. niem.; par. 929 k.c. niem.

${ }^{50}$ M. KasPar, Abschied vom Abstraktions- und Traditionsprinzip? Gemeinsame Strukturen des rechtsgeschäftlichen Mobiliarerwerbs nach „Abstraktionsprinzip" und dem so genannten „reinen Konsensprinzip" am Beispiel eines deutsch-rumänischen Rechtsvergleichs, Berlin 2003, s. 239 i n. 
nictwa odrzuciła izolowanie ważności causae przewłaszczenia od ważności czynności przewłaszczającej. W ten sposób, także polscy sędziowie, bez odnoszenia się w swoim myśleniu do prawa rzymskiego, ukazali dogmatyczny deficyt wynikający $z$ odejścia, od ustalonej już jako zasada rzymskiej traditio kauzalności czynności przewłaszczającej $^{51}$.

\section{KONKLUZJE}

Przystępując do formułowania ogólnych wniosków przypomnę, iż punktem wyjścia niniejszych rozważań stanowiło pytanie, czy realistyczne podejście do prawa pozwala pominąć fakt trwałości zasad wyrastających z prawa rzymskiego?

Opierając się na naszkicowanych wyższej cechach realizmu rzymskich jurystów uznać należy, iż współcześnie, w imię takiej właśnie postawy, nie można podążać za rationes decidendi opartych na nieaktualnym dziś stanie wiedzy o świecie materialnym. Przykładowo, bezkrytycznego ograniczania res corporales do obiektów dotykalnych. Krytycznie należy podejść także do widocznego u jurystów traktowania niektórych zastanych przez nich struktur prawnych jako pierwotne wobec porządku prawnego. Bezkrytyczne przyjęcie takich struktur za podstawę współczesnych rozważań dogmatycznych mogłoby prowadzić do „reprodukcji dogmatyki, którą z punktu ewolucyjnego należałoby uznać za embrionalną"s2. Te uwagi są argumentami przeciwko metodzie dedukcyjnego, dogmatycznego korzystania z prawa rzymskiego współcześnie.

Inspirujące jest natomiast, moim zdaniem, zestawienie właściwego dla realizmu rzymskich jurystów przekonania o istnieniu pierwotnych

${ }^{51}$ Por. W. DAJCZAK, Das Trennungs- und Abstraktionsprinzip. Die Zweifel polnischer Richter bezüglich des Grundstückkaufs im Vergleich mit der romanistischer Diskussion über den dinglichen Vertrag, [w:] Deutsches Sachenrecht in polnischer Gerichtspraxis, red. W. DAJCZAK, H.-G. KNOTHE, Berlin 2005, s. 257 i n.

${ }_{52}$ Por. T. GIARO, Dogmatyka a historia prawa w polskiej tradycji romanistycznej, «K» 37.3-4 (1994), s. 98. 
względem prawa zasad na które powinny być zorientowane wartościujące sądy prawników z trwałością niektórych, wyprowadzonych $\mathrm{z}$ tego przekonania rozwiązań. Przypomnienie takiego punktu wyjścia rationes, ich weryfikacji w ramach ius controversium antycznego Rzymu oraz uświadomionej lub nieuświadomionej kontynuacji po współczesność, nie pozwala, moim zdaniem, zredukować ich trwałości do formalnego aspektu kultury prawnej. $\mathrm{Z}$ tej perspektywy nie przekonuje, wskazane na wstępie stanowisko M. Hesselinka, który pod szyldem realistycznej rewolucji w europejskiej kulturze prawnej przeciwko formalizmowi prawniczemu, krytykuje odniesienia do prawa rzymskiego $\mathrm{w}$ poszukiwaniach europejskiego prawa prywatnego ${ }^{53}$. Taką krytykę należy postrzegać jako kontrowersję co do kształtu realizmu prawniczego. Patrząc szerzej, lokuje się ona w ramach dyskusji o tym, czy prawo to tylko produkt cywilizacji, który może się całkowicie zmienić $w$ ramach nowej kultury prawnej, czy też istnieją niezależne od prawa warunki racjonalności jego tworzenia i stosowania.

Powyższe uwagi skłaniają do wniosku, że realistyczne podejście do prawa, nie pozwala pominąć refleksji nad trwałością zasad wyrastających z prawa rzymskiego gdy uznamy, że podstawą racjonalnych działań prawodawcy i stosujących prawo powinny być pierwotne wobec prawa wymagania rozumności praktycznej ${ }^{54}$.

The Issue of „Timeless” Nature of the Rules of the Roman LaW. REMARKS IN THE DisCuSSION ON „THE NeW EuROPEAN LEGal Culture”

\section{Summary}

Within the scope of a discussion on the new European private law opinions regarding the need for a realist revolution are formulated, which would aim at conquering its formal systematics and dogmatic character.

\footnotetext{
${ }^{53}$ M. Hesselink, op. cit., s. 59 i 65.

${ }^{54}$ Por. J. FinNis, Prawo naturalne i uprawnienia naturalne, Warszawa 2001, s. 325 (tłum. K. Lossman).
} 
From this perspective the references to Roman law are criticised in relation to establishing an extranational private law. They are called neo-pandectism and qualified as dogmatic trends in the European private law.

Referring to that discussion I ask in the article whether the realistic thinking about law allows to ignore the durable rules originating from the Roman law. While presenting the characteristics of the realism of the Roman jurists above all I indicated the conviction of the existence of rules that were primary to law, which should be taken into account in the lawyers' evaluations.

I voiced an opinion that seeing the durability of some of the Roman rationes decidendi there is no point in discussing the references to the Roman tradition in the context of the dispute between the realism and formalism but as an element of a dispute regarding the issue what the realistic thinking about law is.

On the basis of the used sources I formulated a conclusion that the realistic thinking about law does not allow to ignore the reflection on the durability of the rules originating from the Roman law when we assume that the basis of the reasonable actions of the law-making bodies as well as the bodies which apply the law should be requirements of practical reasonableness, which have a primary nature to law. 